Int. J. Dev. Biol. 62: 225-234 (2018)

https://doi.org/10.1387/ijdb.170293jb

\title{
Sonic hedgehog in vertebrate neural tube development
}

\author{
MARYSIA PLACZEK ${ }^{1}$ and JAMES BRISCOE*,2 \\ ${ }^{1}$ The Bateson Centre and Dept. of Biomedical Science, University of Sheffield, Western Bank, Sheffield and \\ ${ }^{2}$ The Francis Crick Institute, London, UK
}

\begin{abstract}
The formation and wiring of the vertebrate nervous system involves the spatially and temporally ordered production of diverse neuronal and glial subtypes that are molecularly and functionally distinct. The chick embryo has been the experimental model of choice for many of the studies that have led to our current understanding of this process, and has presaged and informed a wide range of complementary genetic studies, in particular in the mouse. The versatility and tractability of chick embryos means that it remains an important model system for many investigators in the field. Here we will focus on the role of Sonic hedgehog (Shh) signaling in coordinating the diversification, patterning, growth and differentiation of the vertebrate nervous system. We highlight how studies in chick led to the identification of the role Shh plays in the developing neural tube and how subsequent work, including studies in the chick and the mouse revealed details of the cell intrinsic programs controlling cell fate determination. We compare these mechanisms at different rostral-caudal positions along the neuraxis and discuss the particular experimental attributes of the chick that facilitated this work.
\end{abstract}

KEY WORDS: spinal cord, morphogen, chick, transcriptional network, central nervous system

\section{Introduction}

The vertebrate nervous system arises from the neural tube, the development of which is initiated early in embryogenesis during gastrulation. In amniotes, the neural tube primoridium first becomes recognizable as a thickened epithelium that forms over the midline of the embryo. As development progresses the centre of this epithelial sheet invaginates and its lateral edges rise, the eventual juxtaposition and fusion of these lateral edges forms the dorsal midline of the neural tube (for a full introduction see (Gilbert, 2016)). Hence the neural tube develops as a bilaterally symmetrical pseudostratified epithelium in which the basal surfaces of neural progenitor cells form the lateral edges of the neural tube and the apical surfaces are oriented towards the internal lumen, the central canal. Neural progenitors proliferate and their nuclei undergo a stereotypic interkinetic nuclear movement in which mitosis occurs apically and S phase basally (Lee and Norden, 2013). This results in a substantial expansion in the number of neural progenitors and the initial phase of neural tube development is marked by a considerable increase in tissue size (Kicheva et al., 2014). As neural progenitors differentiate into post-mitotic neurons they detach from the apical surface of the neuroepithelium and migrate laterally to reside basal to the cell bodies of progenitors, a process that can be imaged in high resolution using slice cultures of the chick neural tube (Das and Storey, 2014). This identified a novel cell biological mechanism during neuronal differentiation in which the delamination of newly differentiatied neurons involves the abscission of the apical cell membrane through an actin-myosin-dependent cell constriction and dismantling of the primary cilium.

Although morphologically indistinguishable, neural progenitors rapidly acquire distinct transcriptional identities during development; this determines the mature cell type(s) a progenitor produces. In many regions of the nervous system, the transcriptional programmes depend on the position of the progenitor within the neural tube, (Dessaud et al., 2008; Jessell, 2000; Briscoe and Small 2015). For example, in the ventral half of the forming spinal cord (perhaps the simplest and most conserved region of the neural tube) the spatially restricted expression of a set of homeodomain and bHLH transcription factors, which to a large extent were first defined in the chick (Ericson et al., 1997, Briscoe et al., 2000), divide the neuroepithelium into 6 discrete domains arrayed along the DV axis. Each domain expresses a distinct combination of transcription factors. Gain- and loss-of-function studies have shown that this code controls the differentiated cell type that each progenitor generates (reviewed in (Alaynick et al., 2011; Dessaud

Abbreviations used in this paper: Shh, sonic hedgehog.

\footnotetext{
*Address correspondence to: James Briscoe. The Francis Crick Institute, 1 Midland Road, London NW1 1AT, UK. Tel. + 44 (0)203 796 1388.

E-mail: james.briscoe@crick.ac.uk - (iD) http://orcid.org/0000-0002-1020-5240
} 
et al., 2008)). Thus, in the ventral half of the spinal cord, motor neurons and interneurons are formed. Analogous transcriptional codes are found in other regions of the neural tube and underlie the spatial pattern of neurogenesis in the dorsal half of the spinal cord (reviewed in Lai et al., 2016) and in the brain (for reviews see (Guillemot, 2007; Pearson and Placzek, 2013; Scholpp and Lumsden, 2010). This principle, in which the spatially restricted expression of transcription factors in neural progenitors results in the spatially segregated generation of distinct neuronal subtypes, is the first step in the assembly of functional neuronal circuits. This facilitates the formation of the correct synaptic connections between neighbouring cell types and ensures that newly generated neurons are deposited in locations in which they are exposed to appropriate axon guidance signals. Thus, the later function of the vertebrate nervous system depends on the specific and reliable pattern of TF gene expression in neural progenitors.

The stereotypic patterns of neurogenesis in the neural tube raises the question of how neural progenitors obtain spatial information in order to establish the correct transcription factor expression profile. A series of embryological observations and surgical manipulations in chick embryos focused attention on the notochord, a specialised rod of axial mesoderm that underlies the posterior neural tube. Grafting an ectopic notochord next to the neural tube resulted in the induction of motor neurons and floor plate cells - a group of specialised glial cells occupying the ventral midline of the neural tube (van Straaten et al., 1989; Yamada et al., 1991). Conversely, notochord removal resulted in the absence of the floor plate and motor neurons (van Straaten et al., 1988; Yamada et al., 1991). Equivalent experiments with grafts of floor plate demonstrated that these cells also had a similar activity. The observation that ectopic floor plate cells differentiated immediately adjacent to grafted cells, whereas motor neurons were located at a characteristic distance (Yamada et al., 1991) led to the conclusion that a secreted factor with a graded instructive role established the pattern of cell type generation in the ventral neural tube. This was confirmed and extended by a series of ex-vivo experiments in which explants of notochord/floor plate from chick were co-cultured with neural tissue (Yamada et al., 1993). The use of explanted tissue from the chick neural tube has continued to provide an indispensable assay for the characterisation of patterning signals (e.g. Zagorski et al., 2017) and it highlights some of the advantages of the chick, including the accessibility of embryos, the relative ease of micro-dissection and the ability to grow embryonic tissue in vitro in serum-free defined medium to test the direct effects of signalling factors on isolated tissue.

\section{Sonic hedgehog mediates ventral patterning in the posterior neural tube}

The cloning of Shh in 1993/1994 offered the first insight into the molecular identity of the secreted signal responsible for ventral neural tube patterning (Chang et al., 1994; Echelard et al., 1993; Krauss et al., 1993; Riddle et al., 1993; Roelink et al., 1994). Shh expression coincides with stages at which notochord and floor plate display their patterning activity. Strikingly, ectopic expression of Shh in the dorsal neural tube induces floor plate and motor neuron specification, recapitulating the activity of transplanted notochord and floor plate (Echelard et al., 1993; Krauss et al., 1993; Roelink et al., 1994). Subsequently, Shh was shown to be sufficient for the induction of the cell types normally found in the ventral neural tube (Martí et al., 1995; Roelink et al., 1995). Demonstration of the necessity for Shh came a year later with the analysis of mice in which the Shh gene had been deleted using gene targeting - a technique not available in the chick, and an indication of the power in combining chick and mouse studies (Chiang et al., 1996). Together, the embryological and molecular data suggested that Shh is initially expressed in the notochord and signals to the adjacent neural tube to induce floor plate cells that in turn synthesise and secrete Shh. Secreted Shh is then responsible for the patterning of the neural tube, and the eventual differentiation of its signature cell types, notably the motor neurons and interneurons that will form the characteristic circuits of the spinal cord.

Explant assays using chick neural tissue confirmed that a processed, secreted form of Shh, the ShhN isoform, was responsible for all the inducing activities of Shh (Martí et al., 1995; Roelink et al., 1995). These experiments also demonstrated that the induction of different cell types is controlled by different concentrations of ShhN, with higher concentrations of Shh required for the induction of more ventral cell types, such as floor plate, than for motor neurons (Ericson et al., 1997; Roelink et al., 1995).

Subsequent studies in the chick neural tube suggested that Patched1 (Ptch1) is the Shh receptor (Marigo and Tabin, 1996), an idea that was rapidly confirmed through biochemical binding studies (Marigo et al., 1996). To test the range of Shh signaling in vivo a mutated form of Ptch1 that acted as a dominant inhibitor of Shh signaling was developed (Briscoe et al., 2001). This was introduced into the chick neural tube by in ovo electroporation - a powerful technique that produces mosaic unilateral expression of a mutant protein allowing the cell autonomous and non-autonomous effects of a pertuburation to be assessed directly in individual embryos (eg Briscoe et al., 2001; Kwong et al., 2014). Analysis of the transfected regions demonstrated that inhibiting Shh signalling cell autonomously inhibited the generation of ventral cell types (Briscoe et al., 2001). The cell types affected included not only floor plate and motor neurons, which had been identified by the earlier embryological studies, but also the progenitors of each of the four classes of interneurons generated in the ventral half of the neural tube. Together these studies confirmed that Shh acts in a graded manner over a long range to control the subtype identity and pattern of neurons along the $\mathrm{D}-\mathrm{V}$ axis in the posterior ventral neural tube.

\section{Establishing a Shh gradient in the neural tube}

The secretion, spread and reception of Shh within the neural tube depends on a large set of dedicated proteins, many of which are highly conserved (reviewed in Briscoe and Therond, 2013). Fatty acids covalently modify Shh to affect both its trafficking to lipid rafts, its secretion and its potency (Long et al., 2015; Pepinsky et al., 1998; Porter et al., 1996). The route by which Shh protein is dispersed through the posterior neuroepithelium remains unclear. Immunological assays in both chick and mouse revealed Shh protein in a graded distribution within the ventral neural tube (GritliLinde et al., 2001; Patten and Placzek, 2002; Cohen et al., 2015) Analysis of a transgenic mouse strain containing a fluorescently labeled Shh protein (Shh-GFP), suggested that microtubule based transport traffics Shh from the notochord across cells in the midline of the forming neural tube (the prospective floor plate), possibly in vesicles, to their apical surface, where it is released (Chamberlain 
et al., 2008). Consistent with this, although Shh protein can be observed basolaterally within the neuroepithelium (Gritli-Linde et al., 2001) it accumulates at the apical side of neural progenitors over several cell diameters from the ventral midline of the neural tube. This accumulation of Shh protein appears to be intracellular and associated with the basal body of the primary cilium (Chamberlain et al., 2008). Thus Shh protein might be trafficked apically following its internalization elsewhere on the cell.

Notwithstanding these uncertainties, it is clear that several extracellular and transmembrane proteins influence the spread of Shh protein through the neuroepithelium. Heparin sulphate proteoglycans (HSPGs) have been implicated in binding to many extracellular ligands including Shh, and may govern its rate of spread (Rubin et al., 2002). Moreover the expression of Sulf1, which catalyzes the sulfation of HSPGs, is induced in the ventral neural tube and associated with the accumulation of Shh protein (Danesin et al., 2006). This suggests that HSPGs modulate the distribution of Shh within the neural tube, although their diversity and pleiotropy has made their role difficult to determine.

Several proteins that are transcriptionally regulated by Shh signaling also bind to Shh protein to inhibit the activity and dissemination of Shh. These include Ptch1 and Hhip1, which are upregulated by Shh signaling (Chuang and McMahon, 1999; Goodrich et al., 1996). These block Shh signaling by binding to Shh, sequestering it and/or enhancing its degradation (Briscoe et al., 2001; Chuang et al., 2003; Jeong and McMahon, 2005). Moreover, while Ptch1 is a transmembrane protein, Hhip1 appears to be secreted and acts non-cell-autonomously to antagonize Shh signaling (Holtz et al., 2015; Kwong et al., 2014). Hence the upregulation of Ptch1 and Hhip1 attenuates Shh spread through the neural tissue, leading to a decrease in Shh at more distant, dorsal, positions in the neural tube.

By contrast, a second group of transmembrane proteins, including Cdon, Boc and Gas1, enhance Shh signaling in the posterior neural tube (Allen et al., 2011; 2007; Song et al., 2015; Tenzen et al., 2006). Cdon and Boc are conserved from Drosophila to mammals, while Gas appears to be mammalian-specific. These proteins appear to act as co-receptors for Shh since in mouse the removal of all three results in loss of ventral pattern in the neural tube (Allen et al., 2011). Gain-of-function approaches in the chick spinal cord show that although Cdon and Boc display functional redundancy, they appear to employ distinct molecular mechanisms to execute their HH-promoting effects (Song et al., 2015). The expression of this group of proteins is downregulated by Shh signaling. This has led to the suggestion that this set of proteins enhances Shh signaling during early stages of neural development when the level of Shh protein is low. As Shh production increases, their downregulation decreases the spread and stability of Shh, and in this way, reduces signaling (Allen et al., 2007; Jeong and McMahon, 2005, Song et al., 2015). Together these processes have been proposed to buffer fluctuations in the production or spread of Shh protein to add robustness to ventral patterning.

\section{Mechanism of Shh signaling in the neural tube}

The patterning of the dorso-ventral axis of the posterior neural tube has served as a model for understanding how cells respond to a graded signal. The transmembrane protein Smoothened links the signaling pathway to its intracellular transduction in neural cells (Hynes et al., 2000). Deletion or inhibition of Smo activity abrogates ventral neural tube patterning (Wijgerde etal., 2002). Moreover the concentration effects of Shh protein can be recapitulated in chick neural tissue explants by the graded activation of Smo activity using small molecule antagonists and agonists (Dessaud et al., 2007; Frank-Kamenetsky et al., 2002).

Shh signaling depends on a cell's primary cilia. This was first noticed in mice with mutations in cilia components (Huangfu and Anderson, 2005; Huangfu et al., 2003). Subsequent analyses of ventral neural tube patterning in embryos lacking different ciliary components revealed that cilia are required for maintaining the signaling pathway in its 'off-state' as well as for transducing the active signal (reviewed in Goetz and Anderson, 2010). These studies included analysis of the Taplid3 chick mutant (Davey et al., 2006). This coiled-coiled domain containing protein is a component of the centrosome that forms the basal body of cilia and mutants fail to form cilia (Yin et al., 2009). Consistent with the importance of cilia, many of the Shh signaling components localize to cilia and dynamic changes in their localizations have been implicated in the mechanism of signaling (Corbit et al., 2005; Rohatgi et al., 2007, Stasiulewicz et al., 2015). Nevertheless, many of the molecular details of the signaling pathway, both within and outside the cilium, remain elusive, and patterning of the neural tube is likely to continue to be a valuable model for deciphering the identity, function localisation and regulation of components of the signaling pathway.

For the control of ventral neural tube patterning the pivotal event in the signaling pathway is the post-translational regulation of Gli protein activity (Briscoe and Therond., 2013). In mouse and chick this family consists of three genes, Gli1-3, which are translated into three proteins, two of which (Gli2 and Gli3) can be converted to a repressor form. Like other components of the signal transduction pathway, trafficking through the cilium appears to regulate the activity of Gli proteins, most likely determining their access to protein kinase $A$, which is important for the production of the repressor form of Gli3 and to restrain activation of Gli2 (Tuson et al., 2011). In the absence of Shh, full length forms of Gli2 and Gli3 proteins are proteolytically processed into repressive forms (GliR) in manner that depends on protein kinase $A$ and the presence of a functioning primary cilium. In the presence of Shh, Gli processing is inhibited resulting in the production of transcriptionally active forms of Gli (GliA). This also depends on primary cilia. The net Gli activity that results from the amount of GliA and GliR in a cell regulates the expression of target genes, including the receptor Ptch1, Gli1 and several proneural transcription factors (Briscoe and Therond, 2013)

The precise contribution each Gli protein makes to ventral neural tube patterning differs. The forced expression of a dominant inhibitory form of Gli3 in the chick neural tube inhibits ventral neural tube patterning (Persson et al., 2002; Meyer and Roelink, 2003), consistent with the idea that the Shh-mediated removal of Gli3 repressor function is essential for ventral patterning. Indeed, the loss of Gli3 in mouse results in a dorsal expansion of the cell types specified by low levels of Shh signaling (Persson et al., 2002). Moreover, all but the most ventral cell types (floor plate and immediately-adjacent cells) are recovered in embryos lacking Shh in which Gli3 is also ablated (Litingtung and Chiang, 2000). By contrast, in mouse embryos lacking Gli2 the floor plate is no longer specified and there is a reduction and ventral shift in the formation of other ventral progenitor types (Matise et al., 1998). This indicates that Gli2 is required for the production of cell identi- 
ties requiring the highest levels of Shh signaling.

Genetic experiments in mouse raised the possibility that graded Shh signaling establishes a gradient of Gli activity in the neural tube by progressively inhibiting Gli repressor activity and increasing Gli activator function. In support of this, gain-of-function experiments in the chick using in ovo electropooration indicated that mutated versions of the Gli proteins with different levels of transcriptional activity are sufficient to recapitulate the patterning activity of graded Shh signaling (Stamataki et al., 2005).

It is apparent, however, that there is not a simple relationship between the extracellular concentration of Shh and the level of transcriptional activation produced by Gli proteins. The amplitude of intracellular signaling is highly dynamic (Balaskas et al., 2012; Dessaud et al., 2007; 2010). A transgenic reporter in which the expression of a fluorescent protein is controlled by Gli binding sites indicated that neural progenitors are initially highly sensitive to Shh and the level of transcriptional activation induced by Gli proteins rises rapidly. With time, cells appear to adapt and become desensitized to ongoing Shh exposure, resulting in a decline in Gli transcriptional activity. A consequence of this adaptation is that different concentrations of Shh generate different durations of intracellular Gli activation, effectively creating a temporal dimension to the extent of Shh signalling. The induction of negative feedback, mediated by ligand-dependent antagonists such as Ptch1, might contribute to the desensitization of cells to Shh (Dessaud et al., 2007). Alternatively, features such as differential stability of activator and repressor forms of the Gli proteins and/or differences in the transcriptional regulation of the Gli genes could be responsible for the adaptation (Cohen et al., 2015).

\section{Interpretation of Shh signaling by a transcriptional network in the spinal cord}

How do the observed dynamics of Gli activity result in the spatially restricted expression of the transcription factors that determine progenitor identity and control neuronal subtype identity? Initial studies divided the transcription factors that respond to Shh into two classes based on their mode of regulation: class I genes were defined by being repressed by Shh signaling, conversely class II genes were those 'induced' by Shh (Briscoe et al., 2000). Acombination of gain-of-function experiments in chick and loss-offunction experiments in mouse identified selective cross-repressive interactions between pairs of class I and class II proteins (Briscoe et al., 2000; Ericson et al., 1997). Moreover, many of the transcription factors controlled by Shh were shown to directly interact with co-repressors of the Groucho/TLE family suggesting a prominent role for de-represson in the spatial regulation of gene expression (Muhr et al., 2001). The mutual repression between pairs of transcription factors provides a mechanism to produce the discrete switches in gene expression that delineate the progenitor domains in the neural tube.

In addition to generating discrete spatial switches in gene expression, the regulatory interactions between the Shh responsive transcription factors plays a major role in defining dynamics of the response to Gli activity and the temporal features of neural tube patterning (Balaskas et al., 2012; Cohen et al.,2014; for a review see Cohen et al., 2013). For example, during normal development cells destined to express Nkx2.2 transiently express Olig2 and Pax6 prior to Nkx2.2 (Dessaud et al., 2007). Gain of function experiments in chick embryos indicated that Nkx2.2 represses Olig2 (Novitch et al., 2001). Experimental observations, together with mathematical modeling, suggested that the repressive activity of Olig2 and Pax6 on Nkx2.2, and not solely the sensitivity of Nkx2.2 to Gli activity, is responsible for establishing the spatial pattern of Nkx2.2 gene expression (Balaskas et al., 2012). This same mechanism allows lower levels of Gli activity to maintain the expression Nkx2.2 once it has been induced suggesting a mechanism to maintain stable patterns of gene expression despite the changing levels of Gli activity. The presence of similar regulatory links between transcription factors that define other progenitor boundaries raises the possibility that similar mechanisms are used to interpret the dynamics of Gli activity to establish the ventral pattern of gene expression. In this view, the dynamics of the downstream transcriptional network is responsible for converting the evolving levels of Gli activity into stable patterns of gene expression.

Insight into how different gene regulatory inputs are integrated at the genomic level is beginning to emerge from studies of the cis-regulatory regions of the transcription factors induced by Shh signaling (Oosterveen et al., 2012; 2013; Peterson et al., 2012; Vokes et al., 2007; 2008; Nishi et al., 2015; Kutejova et al., 2016). ChIP and bioinformatic analyses have identified Gli binding sites associated with many of these transcription factors and transgenic reporter assays have confirmed the role of these sites in regulating gene expression (Peterson et al., 2012; Vokes et al., 2007). An unexpected correlation between the affinity of the Gli binding site and the distance from the ventral midline of gene induction was noted (Oosterveen et al., 2012). In conventional models of morphogen signaling, genes that are induced at lower concentrations of a morphogen are more sensitive because they have a high binding affinity for the morphogen-activated transcription factor. By contrast the induction of genes that require high levels of morphogen have a lower affinity binding site. For the targets of Shh-Gli signaling in neural cells the opposite was observed: high affinity Gli binding sites were found associated with genes that are normally induced in response to high levels of Shh-Gli activity and low affinity sites were found in more broadly induced genes. This observation, together with assays in chick embryos of Gli binding sites within cis-regulatory regions led to the suggestion that the mechanisms of short and long-range interpretation of Shh signaling differ. In this view, the context of the Gli binding site means that short range targets require Gli activator and high binding affinity whereas long range targets are regulated through low affinity sites by Gli repressor activity. This raises the question of how the response of cis-regulatory regions elements is determined.

In addition to Gli binding sites, many of the Shh responsive cis-regulatory in neural target genes are associated with binding sites for homeodomain proteins and SoxB proteins (Oosterveen et al., 2012; Peterson et al., 2012). Members of the SoxB family of transcriptional activators (Sox1-3) are broadly expressed throughout the neural tube and function as activators of target genes. Strikingly, the ectopic expression of Sox 2 within cells of the limb is sufficient to allow the Shh-dependent induction of genes such as Nkx2.2 and Nkx6.1 that are normally restricted to neural progenitors (Oosterveen et al., 2013). Thus, SoxB binding appears to confer neural specificity to target genes. Moreover, the number, affinity or arrangement of SoxB binding sites within a regulatory element could influence its response to Gli input. By contrast to the Sox sites, mutation of the homeodomain binding sites in a cis- 
regulatory element indicated that homeodomain protein binding normally mediates a repressive activity (Oosterveen et al., 2012). This supports and extends the genetic experiments that suggest a repressive function of the homeodomain transcription factors regulated by Shh-Gli signaling. Taken together the current model suggests that individual cis-regulatory elements integrate the transcriptional input from Gli proteins, with uniform activation provided by SoxB proteins, and transcriptional repression from the spatially controlled homeodomain transcription factors that comprise the gene regulatory network (Oosterveen et al., 2012; Peterson et al., 2012; Cohen et al., 2014). Together, these constituents control the spatial and temporal dynamics of gene expression in the neural tube.

\section{Floor plate induction}

Although the graded activity of Shh signaling, decoded by the downstream transcriptional network, forms the basis of ventral neural tube patterning, additional mechanisms contribute to the diversification of cell fates. One example of this arises for the specification of the ventral midline floor plate (for a review see (Placzek and Briscoe, 2005). These cells are morphologically and functionally distinct from neural progenitors that reside in the rest of the neural tube. The constricted apical surfaces and basally localized nuclei of floor plate cells is responsible for the characteristic shape of the neural tube and these cells act as a secondary organizing centre by secreting Shh. By contrast to other neural progenitors, which acquire their characteristic transcriptional identities after neural tube closure, the induction of the floor plate requires exposure to Shh signaling at an earlier time point (Ribes et al., 2010; Sasai et al., 2014). Gain- and loss-of-function experiments indicate that only cells in the open neural plate are competent to form floor plate in response to Shh signaling. Moreover, following this early induction, components of Shh signaling are rapidly downregulated in presumptive floor plate cells, halting further signaling. This termination of signaling is necessary for floor plate differentiation and might also allow floor plate cells to secrete Shh efficiently, since the upregulation of Ptch 1 and other $\mathrm{Hh}$ binding factors in cells responding to Shh would likely sequester the ligand. Thus, floor plate induction emphasizes the importance of timing and dynamics for the response of neural cells to Shh-Gli signaling.

\section{Shh signaling in anterior regions of the neural tube}

Sh is expressed along the entire anterior-posterior (future rostro-caudal) length of the axial mesoderm and ventral midline of the neural tube (Riddle et al., 1993; Roelink et al., 1994). Exposure of chick neural explants dissected from different anterior-posterior positions to Shh, implantation of Shh-soaked beads at different axial positions or localised constitutive activation of Smo indicated that Shh induces a wide variety of ventral neurons of the brain, including interneurons of the telencephalon and diencephalon, dopaminergic neurons of the hypothalamus and midbrain and serotonergic neurons of the hindbrain (Ericson et al., 1995; Wang et al., 1995; Gunhaga et al., 2000; Craven et al., 2004; Ohyama et al., 2005). The importance of Shh throughout the neural tube was confirmed by the loss of ventral cell types in mouse embryos lacking the Shh gene (Chiang et al., 1996) and the discovery that HPE, a human congenital malformation in which ventral areas of the brain are not properly formed, results from disruption to Shh expression or signaling (Belloni et al., 1996; Roessler et al., 1996).

Targeted electroporation in chick, involving gain- and loss-offunction studies of homeodomain transcription factors, proved that the region specific outcome of Shh signaling depends on the expression of a set transcription factors that are established by earlier anterior-posterior cues. Six3, Irx3, and Otx2, for instance, promote expression of Nkx2.1, Nkx6.1, Dlx2 and Gbx2 in response to Shh, and hence hypothalamic, diencephalic and midbrain fates (Watanabe and Nakamura, 2000; Kobayashi et al., 2002; Ohyama et al., 2005; Kiecker and Lumsden, 2004)

For a brief early period, similar patterns of Gli genes are detected along the dorso-ventral axis in the anterior neural tube to those described posteriorly. Thus in both the chick and mouse anterior neural tube, Gli1, Gli2 and Gli3 are expressed in overlapping but distinct domains, Gli1 in ventral-midline cells, Gli2 in ventral and intermediate regions and Gli3, dorsally (Aglyamova and Agarwala, 2007; Ohyama et al., 2008). Further, some of the same homeodomain transcription factors as the prospective spinal cord are involved. For instance, Foxa1 is transiently expressed in the ventral midline, whilst Nkx2.2, Pax6 and Dbx1 are expressed more distantly (Chapman et al., 2002; Ferran et al., 2007). Analyses of Gli mouse mutants reveals that, similar to the prospective spinal cord, in the anterior neuraxis Gli2 performs the main GliA function and that Shh counteracts Gli3 (eg. Haddad-Tovolli et al., 2015). However, there are differences. In Gli2 mutant mice (that lack Shh expression in posterior floor plate cells), Shh-expressing ventral midline cells persist in the anterior neural tube (Ding et al., 1998; Matise et al., 1998). Subsequent studies, analysing Shh enhancer elements, described a unique enhancer, SBE2 (Shh brain enhancer 2) that drives expression in rostral diencephalic ventral midline (RDVM) cells (Jeong et al., 2006).

Studies in chick contributed to unravelling how Shh is regulated in the anterior neuraxis and highlighted differences to the prospective spinal cord. Fate mapping studies showed that RDVM cells are underlain by axial prechordal mesendoderm (PM), not notochord (Dale et al., 1997). RDVM cells are absent if PM is removed; conversely, grafting an ectopic PM next to the neural tube resulted in the induction of RDVM-like cells (Pera and Kessel., 1997; Patten et al., 2003; García-Calero et al., 2008). Ex vivo studies in which PM was cultured with neural tissue showed that PM can induce RDVM cells and initiate further ventral pattern (Dale et al.,. 1997; Dale et al., 1999; Ohyama et al., 2005; Hintze et al., 2017). PM, like notochord, expresses Shh (Patten et al., 2003; Ellis et al., 2015; Shimamura et al., 1995), and blockade or genetic ablation of Shh activity in the PM abrogates its ability to induce RDVM cells (Dale et al., 1997; Shimamura and Rubenstein, 1997; Patten et al., 2003; Geng et al., 2008; Aoto et al., 2009). Further, while mouse embryos in which Shh is conditionally deleted in the PM show cyclopia, those in which Shh is conditionally deleted in RDVM cells do not (Szabo et al., 2009). Therefore, the holoprosencephalic phenotypes that arise when Shh or Shh signaling are deregulated arise due to a failure of RDMV induction by PM (Roessler and Muenke, 2010). Nevertheless, exposure of neural tube explants to purified Shh protein revealed that Shh is not sufficient to induce RDVM cells. Instead, Shh acts co-operatively with the TGFb-ligand, Nodal, with which it is transiently expressed in the PM (Patten et al., 2003; Ellis et al., 2015). Loss-of-function studies in mouse and zebrafish, and analyses of human patients, suggest that a Shh-Nodal co-operation may be widely conserved and that Shh and Nodal 
signaling pathways are required cell-autonomously in RDVM cells (Mathieu et al., 2002; reviewed in (Placzek and Briscoe, 2005)). At present, the mechanism is not known, but this could be examined in chicks, for instance, by asking whether Shh and Nodal form part of a gene regulatory network that includes the TF, Six3, known to be responsive to Shh and to activate SBE2 (Geng et al., 2008; Jeong et al., 2008).

Studies in chick and mouse show that RDVM cells give rise to a highly proliferative hypothalamic progenitor population (Manning et al., 2006; Alvarez-Bolado et al., 2012; Fu et al., 2017). The transition from RDVM to proliferating hypothalamic progenitors appears to be mediated by the PM. During the time the PM is adjacent to RDVM cells, Shh/Nodal expression declines and BMP expression increases (Dale et al., 1999; Ellis et al., 2015). Exposure of RDVM explants to BMPs upregulates the transcriptional repressor, Tbx2 and the signaling factor, Fgf10. Loss-of-function studies, electroporating a Tbx2 siRNA construct into chick RDVM cells showed that Tbx2 is required to downregulate Shh in RDVM cells and to promote cell cycle (Manning et al., 2006). Explant culture studies show that Fgf signals in an autocrine manner to promote proliferation of hypothalamic progenitors (Pearson et al., 2011). Studies in mice extended this work, showing that Tbx2 and Tbx3 repress Shh by sequestering Sox 2 away from a Shh cis-regulatory element (Trowe et al., 2013), again, highlighting the importance of SoxB1 genes as activators of neural expression and their intimate association with Shh in the neural tube.

Recent fate-mapping experiments in chick and mouse show that RDVM-derived hypothalamic progenitors are a multipotent population and contribute widely to different subsets of hypothalamic progenitors (Alvarez-Bolado et al., 2012; Fu et al., 2017). In chick, RDVM-derived hypothalamic progenitors give rise to anterior, tuberal and mamillary progenitors along the rostro-caudal axis,, each of which grows and differentiates sequentially over time (Fu et al., 2017). This shows an exquisite coupling of growth and fate in the hypothalamus, a process in which Shh signaling plays an essential role. Transient blockade of Shh signaling in the chick embryo prevents the growth of anterior progenitors (Fu et al., 2017). Studies in mouse and zebrafish suggests a potential mechanism, in which Shh induces the paired-like homeodomain $\mathrm{TF}, \mathrm{Rx} / \mathrm{rx} 3$ in hypothalamic progenitors, a determinant of anterior progenitor fate and growth. The subsequent down-regulation of $\mathrm{Rx} / \mathrm{rx3}$, by Shh, is required to realize hypothalamic fate. In the absence of $\mathrm{Rx} / \mathrm{rx} 3$, anterior progenitors fail to grow and neurons characteristic of the anterior and tuberal hypothalamus fail to differentiate (Muthu et al., 2015; Orquera et al.,. 2015). Amongst the genes upregulated or maintained in anterior progenitors by $\mathrm{Rx} /$ rx3 is Shh itself. Thus a regulatory loop between Shh and Rx/rx3, coupled to growth, may explain the complex pattern of expression of Shh in the hypothalamus, in which it is downregulated in central-most hypothalamic progenitors, but maintained/upregulated in emerging anterior progenitors. The notion that Shh-expressing anterior progenitors are a dynamic population provides an explanation for genetic lineage-tracing studies in the mouse, which reveal their extensive, but dynamic contribution to hypothalamic neurons (Szabo et al., 2009; Shimogori et al., 2010; Zhao et al., 2012; Haddad-Tovolli et al., 2015).

Central to this regulatory loop is the ability of Shh to nonautonomously induce $\mathrm{Rx} / \mathrm{rx} 3$ and autonomously down-regulate it. In the posterior neural tube, autonomous and non-autonomous events are driven through the dyamic expression of Ptch1 and Hhip. In the hypothalamus, Ptch1 is rapidly downregulated in central hypothalamic progenitors, halting further signaling (Manning et al., 2006). Potentially, this enables them to secrete Shh efficiently, supporting its spread and the sustained maintenace/ induction of Rx/rx3 anteriorly. Thus, as in the spinal cord, it is likely that Shh-activated genes can attenuate the effects of Shh signaling, confining the regional and temporal expression and actions of Shh. Whether the effects of Shh-activated co-receptors will operate in the same manner as in the spinal cord remains to be determined. Intriguingly, in the optic vesicle, in the absence of Ptc co-expression Cdon acts as a sink for Hh proteins, potentially limiting their spread (Cardozo et al., 2014). Additionally, Shh signaling may be attenuated by genes that are exclusive to the forebrain. The low-density lipoprotein receptor-related protein 2 (LRP2; megalin) has been implicated as a Shh coreceptor in the forebrain and has been suggested to concentrate Shh in the ventral forebrain at an appropriate developmental time (Christ et al., 2012).

The intricate regulation of induction and cessation of Shh signaling in sets of neighboring cells, coupled with the ability of Shh to integrate growth and differentiation, creates a temporal dimension that provides the opportunity to build increasingly complex arrays of neurons. The hypothalamus, for instance, contains a vast array of neurons that centrally regulate complex homeostatic processes that are essential to survival and species propagation.

Similarly, dynamic neural Shh-Gli activity underlies development of the thamalic complex, a region of the brain that processes and relays sensory and motor information to and from the cortex. The thalamic complex is composed of the pre-thalamus (anteriorly) and the thalamus (posteriorly), bissected through a narrow compartment, the zona limitans intrathalamica (ZLI) that expresses Shh. Studies of chimeric chick embryos generated through classic surgical manipulation, or explant apposition experiments, showed that the formation of the $\mathrm{ZLI}$ is due to an interaction between anterior and posterior neuroepithelia (Vieira et al., 2005; Guinazu et al., 2007). Targeted electoporation studies subsequently showed that the ZLI is induced through cross-repressive TF interactions (reviewed in Scholpp and Lumsden, 2010). Shh expression was found to be induced progressively in the ZLI, from ventral to dorsal. As in the hypothalamus, this appears to be mediated through an autoinduction mechanism (Vieira et al., 2005). Grafting and explant experiments in chick embryos revealed that the mid-diencephalic ZLI displays organizer activity, inducing thalamic and prethalamic characteristics (Guinazu et al., 2007; Vieira et al., 2005). Further, Shh-Gli was shown to mediate a significant extent of the organizing activity of the ZLI. Gain- and loss-of-function experiments using in ovo electroporation showed that Shh signaling is required for region-specific gene expression in the thalamus and prethalamus (Kiecker and Lumsden, 2004). Similarly, ectopic activation of the Shh pathway by misexpression of Smo, or GliAs induced the expression of thalamic markers (Vue et al., 2007; Hashimoto-Torii et al., 2003). Early indications suggested that Shh deriving from the MDO/ZLI spreads along the A-P axis, and acts as a morphogen to pattern the AP axis of the thalamus in a similar way to its actions along the dorsoventral axis of the spinal cord, generating 3 distinctive progenitor domains (pTH-R, closest to the zli, pTH-C and $\mathrm{pTH}-\mathrm{C}_{1}$ ) whose transcriptional profiles are similar to those of the 3 ventral-most progenitor domains of the spinal cord (reviewed in Epstein, 2012; Scholpp and Lumsden, 2010). Recent studies, 
however, suggest a more complex model, in which Shh arising from the basal plate plays a role in pTH-R progenitor specification, potentially contributing to increased levels or durations of signalling (Jeong et al., 2011; reviewed in Epstein, 2012). As in the hypothalamus, we are still some way from understanding the complex manner in which Shh integrates patterning, growth and differentiation to build the thalamic complex.

\section{Conclusion}

Collectively, the studies of the last two decades have revealed the multiple roles that Shh plays in the development of the vertebrate nervous system. Reciprocally, the analysis of neural tube development has provided multiple insights into Shh signaling. The chick embryo has featured prominently in many of these studies and through this work we have gained new mechanistic insights into how a single signal can perform several functions and produce an ordered pattern of diverse cell types in a complex tissue. Not only have these insights deepened our understanding of fundamental developmental processes but they have aso been a major influence in the establishment of methods for the directed differentiation of specific neuronal subtypes from embryonic stem cells in vitro (Wichterle et al., 2002); Cundiff and Anderson, 2011; Liu and Zhang, 2010). Moreover the transplantation of stem cell-derived neurons back into chick has resulted in successful engraftment (Wichterle et al., 2002), raising the hope that this could provide an eventual route to cell based therapies for some neurodegenerative diseases. Despite the progress, much remains to be discovered about Shh signaling and neural tube development. Approaches that provide live, high-resolution measurements of the activity of key components of the pathway are necessary to decipher the signaling mechanism and provide insight into the dynamics of signal transmission through the pathway. Similarly, understanding how Shh signaling regulates differential gene expression to control cell fate decisions will benefit from the increased precision and resolution that new technologies are beginning to offer. It seems likely that the chick will continue to play a leading role in these approaches.

\section{Acknowledgements}

We thank Philip Ingham for comments on an earlier draft of this article and Anne-Gaelle Borycki and Matthew Towers for comments on this article. Work in JB's lab is supported by the Francis Crick Institute which receives its core funding from Cancer Research UK (FC001051), the UK Medical Research Council (FC001051), and the Wellcome Trust (FC001051); by the Wellcome Trust (WT098326MA); and by the BBSRC (BB/J015539/1).

\section{References}

AGLYAMOVA, G.V. AND AGARWALA, S. (2007). Gene expression analysis of the hedgehog signaling cascade in the chick midbrain and spinal cord. Dev Dyn. 236: 1363-1373.

ALAYNICK, W.A., JESSELL, T.M., AND PFAFF, S.L. (2011). SnapShot: spinal cord development. Cell 146: 178-178.

ALLEN, B.L., TENZEN, T. AND MCMAHON, A.P. (2007) The Hedgehog-binding proteins Gas1 and Cdo cooperate to positively regulate Shh signaling during mouse development. Genes Dev. 21: 1244-1257

ALLEN, B.L., SONG, J.Y., IZZI, L., ALTHAUS, I.W., KANG, J.S., CHARRON, F., KRAUSS, R.S., AND MCMAHON, A.P. (2011). Overlapping roles and collective requirement for the coreceptors GAS1, $\mathrm{CDO}$, and $\mathrm{BOC}$ in $\mathrm{SHH}$ pathway function. Dev. Cell 20: 775-787.

ALVAREZ-BOLADO, G., PAUL, F. A. AND BLAESS, S. (2012) Sonic hedgehog lineage in the mouse hypothalamus: from progenitor domains to hypothalamic regions. Neural Dev. 7: 4.

AOTO, K., SHIKATA, Y., IMAI, H., MATSUMARU, D., TOKUNAGA, T., SHIODA, S. YAMADA, G. AND MOTOYAMA, J. (2009) Mouse Shh is required for prechorda plate maintenance during brain and craniofacial morphogenesis. Dev Biol. 327: 106-120.

BALASKAS, N., RIBEIRO, A., PANOVSKA, J., DESSAUD, E., SASAI, N., PAGE, K.M., BRISCOE, J., AND RIBES, V. (2012). Gene regulatory logic for reading the Sonic Hedgehog signaling gradient in the vertebrate neural tube. Cell 148: 273-284.

BELLONI, E., MUENKE, M., ROESSLER, E., TRAVERSO, G., SIEGEL-BARTELT, J., FRUMKIN, A., MITCHELL, H.F., DONIS-KELLER, H., HELMS, C., HING, A.V., HENG HH, KOOP B, MARTINDALE D, ROMMENS JM, TSUI LC, SCHERER SW. (1996). Identification of Sonic hedgehog as a candidate gene responsible for holoprosencephaly. Nat Genet 14: 353-356.

BRISCOE, J., CHEN, Y., JESSELL, T.M., AND STRUHL, G. (2001). A hedgehoginsensitive form of patched provides evidence for direct long-range morphogen activity of sonic hedgehog in the neural tube. Mol. Cell 7: 1279-1291.

BRISCOE, J., PIERANI, A., JESSELL, T.M., AND ERICSON, J. (2000). A homeodomain protein code specifies progenitor cell identity and neuronal fate in the ventral neural tube. Cell 101: 435-445.

BRISCOE, J., SMALL, S. 2015. Morphogen rules: design principles of gradientmediated embryo patterning. Development 142: 3996-4009.

BRISCOE, J., THÉROND, P.P. 2013. The mechanisms of Hedgehog signalling and its roles in development and disease. Nat. Rev. Mol. Cell Biol. 14: 416-429.

CARDOZO, M.J., SÁNCHEZ-ARRONES, L., SANDONIS, A., SÁNCHEZ-CAMACHO, C., GESTRI, G., WILSON, S.W., GUERRERO, I. AND BOVOLENTA, P. (2014) Cdon acts as a Hedgehog decoy receptor during proximal-distal patterning of the optic vesicle. Nat Commun. 5: 4272.

CHAMBERLAIN, C.E., JEONG, J., GUO, C., ALLEN, B.L., AND MCMAHON, A.P. (2008). Notochord-derived Shh concentrates in close association with the apically positioned basal body in neural target cells and forms a dynamic gradient during neural patterning. Development 135: 1097-1106.

CHANG, D.T., LÓPEZ, A., KESSLER, VON, D.P., CHIANG, C., SIMANDL, B.K., ZHAO, R., SELDIN, M.F., FALLON, J.F., AND BEACHY, P.A. (1994). Products, genetic linkage and limb patterning activity of a murine hedgehog gene. Development 120: 3339-3353.

CHAPMAN, S.C., SCHUBERT, F.R., SCHOENWOLF, G.C. AND LUMSDEN, A. (2002). Analysis of spatial and temporal gene expression patterns in blastula and gastrula stage chick embryos. Dev Biol. 245: 187-99

CHIANG, C., LITINGTUNG, Y., LEE, E., YOUNG, K.E., CORDEN, J.L., WESTPHAL, H., AND BEACHY, P.A. (1996). Cyclopia and defective axial patterning in mice lacking Sonic hedgehog gene function. Nature 383: 407-413.

CHRIST, A., CHRISTA, A., KUR, E., LIOUBINSKI, O., BACHMANN, S., WILLNOW T.E., AND HAMMES, A. (2012). LRP2 is an auxiliary SHH receptor required to condition the forebrain ventral midline for inductive signals. Dev. Cell22:268-278.

CHUANG, P.T., AND MCMAHON, A.P. (1999). Vertebrate Hedgehog signalling modulated by induction of a Hedgehog-binding protein. Nature 397: 617-621.

CHUANG, P.T., KAWCAK, T., AND MCMAHON, A.P. (2003). Feedback control of mammalian Hedgehog signaling by the Hedgehog-binding protein, Hip1, modulates Fgf signaling during branching morphogenesis of the lung. Genes Dev. 17: 342-347.

COHEN, M., BRISCOE, J., ANDBLASSBERG, R. (2013). Morphogen interpretation: the transcriptional logic of neural tube patterning. Curr. Opin. Genet. Dev. 23,423-428

COHEN, M., PAGE, K.M., PEREZ-CARRASCO, R., BARNES, C.P., BRISCOE, J. (2014). A theoretical framework for the regulation of Shh morphogen-controlled gene expression. Development 141: 3868-3878

COHEN, M., KICHEVA, A., RIBEIRO, A., BLASSBERG, R., PAGE, K.M., BARNES, C.P., BRISCOE, J. (2015). Ptch1 and Gli regulate Shh signalling dynamics via multiple mechanisms. Nat. Commun. 6: 6709

CORBIT, K.C., AANSTAD, P., SINGLA, V., NORMAN, A.R., STAINIER, D.Y.R., AND REITER, J.F. (2005). Vertebrate Smoothened functions at the primary cilium. Nature 437: 1018-1021.

CRAVEN, S.E., LIM, K-C., YE, W., ENGEL, J.D., DE SAUVAGE, F., AND ROSENTHAL, A. (2004) Gata2 specifies serotonergic neurons downstream of sonic hedgehog. Development 131: 1165-1173.

CUNDIFF, P.E., AND ANDERSON, S.A. (2011). Impact of induced pluripotent stem 
cells on the study of central nervous system disease. Curr. Opin. Genet. Dev. 21: 354-361.

DALE, J.K, VESQUE, C., LINTS, T.J., SAMPATH, T.K., FURLEY, A., DODD, J. AND PLACZEK, M. (1997). Cooperation of BMP7 and SHH in the induction of forebrain ventral midline cells by prechordal mesoderm. Cell 90: 257-69.

DALE, K., SATTAR, N., HEEMSKERK, J., CLARKE, J.D., PLACZEK, M. AND DODD, J. (1999). Differential patterning of ventral midline cells by axial mesoderm is regulated by BMP7 and chordin. Development. 126: 397-408.

DANESIN, C., AGIUS, E., ESCALAS, N., AI, X., EMERSON, C., COCHARD, P., AND SOULA, C. (2006). Ventral neural progenitors switch toward an oligodendroglial fate in response to increased Sonic hedgehog (Shh) activity: involvement of Sulfatase 1 in modulating Shh signaling in the ventral spinal cord. J. Neurosci. 26: $5037-5048$

DAS, R.M., STOREY, K.G. (2014). Apical abscission alters cell polarity and dismantles the primary cilium during neurogenesis. Science. 343: 200-20

DAVEY, M.G., PATON, I.R., YIN, Y., SCHMIDT, M., BANGS, F.K., MORRICE, D.R., SMITH, T.G., BUXTON, P., STAMATAKI, D., TANAKA, M., MÜNSTERBERG, A.E., BRISCOE, J., TICKLE, C., BURT, D.W. (2006). The chicken talpid3 gene encodes a novel protein essential for Hedgehog signaling. Genes Dev. 20: 1365-1377.

DESSAUD, E., MCMAHON, A.P., AND BRISCOE, J. (2008). Pattern formation in the vertebrate neural tube: a sonic hedgehog morphogen-regulated transcriptional network. Development 135: 2489-2503.

DESSAUD, E., RIBES, V., BALASKAS, N., YANG, L.L., PIERANI, A., KICHEVA, A., NOVITCH, B.G., BRISCOE, J., AND SASAI, N. (2010). Dynamic assignment and maintenance of positional identity in the ventral neural tube by the morphogen sonic hedgehog. PLOS Biol. 8: e1000382.

DESSAUD, E., YANG, L.L., HILL, K., COX, B., ULLOA, F., RIBEIRO, A., MYNETT, A., NOVITCH, B.G., AND BRISCOE, J. (2007). Interpretation of the sonic hedgehog morphogen gradient by a temporal adaptation mechanism. Nature 450: 717-720.

DING, Q.. MOTOYAMA, J., GASCA, S., MO, R., SASAKI, H., ROSSANT, J. AND HUI, C.C. (1998) Diminished Sonic hedgehog signaling and lack of floor plate differentiation in Gli2 mutant mice. Development 125: 2533-2543.

ECHELARD, Y., EPSTEIN, D.J., ST-JACQUES, B., SHEN, L., MOHLER, J., MCMAHON, J.A., AND MCMAHON, A.P. (1993). Sonic hedgehog, a member of a family of putative signaling molecules, is implicated in the regulation of CNS polarity. Cell 75: 1417-1430.

ELLIS, P.S., BURBRIDGE, S., SOUBES, S., OHYAMA, K., BEN-HAIM, N., CHEN, C., DALE, K., SHEN, M.M., CONSTAM,D. AND PLACZEK, M. (2015) ProNodal acts via FGFR3 to govern duration of Shh expression in the prechordal mesoderm. Development. 142: 3821-32.

EPSTEIN, D.J. (2012). Regulation of thalamic development by sonic hedgehog. Front Neurosci 6: 57.

ERICSON, J., MUHR, J., PLACZEK, M., LINTS, T., JESSELL, T.M., AND EDLUND, T. (1995). Sonic hedgehog induces the differentiation of ventral forebrain neurons: a common signal for ventral patterning within the neural tube. Cell 81: 747-756.

ERICSON, J., RASHBASS, P., SCHEDL, A., BRENNER-MORTON, S., KAWAKAMI, A., VAN HEYNINGEN, V., JESSELL, T.M., AND BRISCOE, J. (1997). Pax6 controls progenitor cell identity and neuronal fate in response to graded Shh signaling. Cell 90: 169-180.

FERRAN, J.L., SÁNCHEZ-ARRONES, L., SANDOVAL, J.E. AND PUELLES, L. (2007). A model of early molecular regionalization in the chicken embryonic pretectum. J Comp Neurol. 505: 379-403.

FRANK-KAMENETSKY, M., ZHANG, X.M., BOTTEGA, S., GUICHERIT, O., WICHTERLE, H., DUDEK, H., BUMCROT, D., WANG, F.Y., JONES, S., SHULOK, J., RUBIN, L.L., PORTER, J.A. (2002). Small-molecule modulators of Hedgehog signaling: identification and characterization of Smoothened agonists and antagonists. J. Biol. 1: 10.

FU, T., TOWERS, M. AND PLACZEK, M.A. (2017) Fgf10+ progenitors give rise to the chick hypothalamus by rostral and caudal growth and differentiation. Development 144: 3278-3288

GARCÍA-CALERO, E., FERNÁNDEZ-GARRE, P., MARTíNEZ, S., AND PUELLES, L. (2008). Early mammillary pouch specification in the course of prechordal ventralization of the forebrain tegmentum. Dev. Biol. 320: 366-377.

GENG, X., SPEIRS, C., LAGUTIN, O., INBAL, A., LIU, W., SOLNICA-KREZEL, L., JEONG, Y., EPSTEIN, D.J., AND OLIVER, G. (2008). Haploinsufficiency of Six3 fails to activate Sonic hedgehog expression in the ventral forebrain and causes holoprosencephaly. Dev. Cell 15: 236-247.

GILBERT, S.F. AND BARRESI M.J.F (2016). Developmental Biology. Eleventh Edition Sunderland (Massachusetts): Sinauer Associates. (ISBN: 978-1-60535-470-5).

GOETZ, S.C., AND ANDERSON, K.V. (2010). The primary cilium: a signalling centre during vertebrate development. Nat. Rev. Genet. 11: 331-344.

GOODRICH, L.V., JOHNSON, R.L., MILENKOVIC, L., MCMAHON, J.A., AND SCOTT, M.P. (1996). Conservation of the hedgehog/patched signaling pathway from flies to mice: induction of a mouse patched gene by Hedgehog. Genes Dev. 10: 301-312.

GRITLI-LINDE, A., LEWIS, P., MCMAHON, A.P., AND LINDE, A. (2001). The whereabouts of a morphogen: direct evidence for short- and graded long-range activity of hedgehog signaling peptides. Dev. Biol. 236: 364-386.

GUILLEMOT, F. (2007). Cell fate specification in the mammalian telencephalon. Prog. Neurobiol. 83: 37-52.

GUINAZU, M.F., CHAMBERS, D., LUMSDEN, A., AND KIECKER, C. (2007). Tissue interactions in the developing chick diencephalon. Neural Dev 2: 25.

GUNHAGA, L., JESSELL, T.M., AND EDLUND, T. (2000). Sonic hedgehog signaling at gastrula stages specifies ventral telencephalic cells in the chick embryo. Development 127: 3283-3293.

HADDAD-TÓVOLLI, R., PAU,L F.A., ZHANG, Y., ZHOU, X., THEIL, T., PUELLES L., BLAESS, S. AND ALVAREZ-BOLADO, G. (2015). Differential requirements for Gli2 and Gli3 in the regional specification of the mouse hypothalamus. Front Neuroanat. 25: 34.

HASHIMOTO-TORII, K., MOTOYAMA, J., HUI, C.C., KUROIWA, A., NAKAFUKU, M. AND SHIMAMURA, K. (2003) Differential activities of Sonic hedgehog mediated by Gli transcription factors define distinct neuronal subtypes in the dorsal thalamus. Mech Dev. 120: 1097-111.

HINTZE, M., PRAJAPATI, R.S., TAMBALO, M., CHRISTOPHOROU, N.A.D., ANWAR, M., GROCOTT, T. AND STREIT, A. (2017) Cell interactions, signals and transcriptional hierarchy governing placode progenitor induction. Development. 144: $2810-2823$

HOLTZ, A.M., GRIFFITHS, S.C., DAVIS, S.J., BISHOP, B., SIEBOLD, C., ALLEN, B.L., 2015. Secreted HHIP1 interacts with heparan sulfate and regulates Hedgehog ligand localization and function. J. Cell Biol. 209: 739-758.

HUANGFU, D., AND ANDERSON, K.V. (2005). Cilia and Hedgehog responsiveness in the mouse. Proc. Natl. Acad. Sci. USA 102: 11325-11330.

HUANGFU, D., LIU, A., RAKEMAN, A.S., MURCIA, N.S., NISWANDER, L., AND ANDERSON, K.V. (2003). Hedgehog signalling in the mouse requires intraflagellar transport proteins. Nature 426: 83-87.

HYNES, M., YE, W., WANG, K., STONE, D., MURONE, M., SAUVAGE, F.D., AND ROSENTHAL, A. (2000). The seven-transmembrane receptor smoothened cell-autonomously induces multiple ventral cell types. Nat. Neurosci. 3: 41-46.

JEONG, J., AND MCMAHON, A.P. (2005). Growth and pattern of the mammalian neural tube are governed by partially overlapping feedback activities of the hedgehog antagonists patched 1 and Hhip1. Development 132: 143-154.

JEONG, Y., EL-JAICK, K., ROESSLER, E., MUENKE, M. AND EPSTEIN, D.J. (2006) A functional screen for sonic hedgehog regulatory elements across a $1 \mathrm{Mb}$ interval identifies long-range ventral forebrain enhancers. Development. 133: 761-72.

JEONG, Y., LESKOW, F.C., EL-JAICK, K., ROESSLER, E., MUENKE, M., YOCUM, A., DUBOURG, C., LI, X., GENG, X., OLIVER, G.AND EPSTEIN, D.J. (2008). Regulation of a remote Shh forebrain enhancer by the Six3 homeoprotein. Nat Genet. 40: 1348-1353.

JEONG, Y., DOLSON, D.K., WACLAW, R.R., MATISE, M.P., SUSSEL, L., CAMPBELL, K., KAESTNER, K.H., AND EPSTEIN, D.J. (2011). Spatial and temporal requirements for sonic hedgehog in the regulation of thalamic interneuron identity. Development 138: 531-541.

JESSELL, T.M. (2000). Neuronal specification in the spinal cord: inductive signals and transcriptional codes. Nat. Rev. Genet. 1: 20-29.

KICHEVA, A., BOLLENBACH, T., RIBEIRO, A., VALLE, H.P., LOVELL-BADGE, R. EPISKOPOU, V., BRISCOE, J. (2014). Coordination of progenitor specification and growth in mouse and chick spinal cord. Science 345: 1254927

KIECKER, C., AND LUMSDEN, A. (2004). Hedgehog signaling from the ZLI regulates diencephalic regional identity. Nat. Neurosci. 7: 1242-1249.

KOBAYASHI D, KOBAYASHI M, MATSUMOTO K, OGURA T, NAKAFUKU M SHIMAMURA K. (2002). Early subdivisions in the neural plate define distinct competence for inductive signals. Development. 129: 83-93. 
KRAUSS, S., CONCORDET, J.P., AND INGHAM, P.W. (1993). A functionally conserved homolog of the Drosophila segment polarity gene hh is expressed in tissues with polarizing activity in zebrafish embryos. Cell 75: 1431-1444.

KUTEJOVA, E., SASAI, N., SHAH, A., GOUTI, M., BRISCOE, J. (2016). Neural Progenitors Adopt Specific Identities by Directly Repressing All Alternative Progenitor Transcriptional Programs. Dev. Cell 36: 639-653

KWONG, L., BIJLSMA, M.F., ROELINK, H., 2014. Shh-mediated degradation of Hhip allows cell autonomous and non-cell autonomous Shh signalling. Nat. Commun. 5: 4849

LAI, H.C., SEAL, R.P., JOHNSON, J.E. (2016). Making sense out of spinal cord somatosensory development. Development 143: 3434-3448.

LEE, H.O., AND NORDEN, C. (2013). Mechanisms controlling arrangements and movements of nuclei in pseudostratified epithelia. Trends Cell Biol. 23: 141-150.

LITINGTUNG, Y., AND CHIANG, C. (2000). Specification of ventral neuron types is mediated by an antagonistic interaction between Shh and Gli3. Nat. Neurosci. 3: 979-985.

LIU, Y., AND ZHANG, S.-C. (2010). Human stem cells as a model of motoneuron development and diseases. Ann. N. Y. Acad. Sci. 1198: 192-200.

LONG, J., TOKHUNTS, R., OLD, W.M., HOUEL, S., RODGRIGUEZ-BLANCO, J., SINGH, S., SCHILLING, N.J., CAPOBIANCO, A., AHN, N.G. AND ROBBINS D.J. (2015) Identification of a family of fatty-acid-speciated sonic hedgehog proteins, whose members display differential biological properties. Cell Rep. 10:1280-1287.

MANNING, L., OHYAMA, K., SAEGER, B., HATANO, O., WILSON, S.A., LOGAN, M., AND PLACZEK, M. (2006). Regional morphogenesis in the hypothalamus: a BMP-Tbx2 pathway coordinates fate and proliferation through Shh downregulation. Dev. Cell 11: 873-885.

MARIGO, V AND TABIN, C.J. (1996). Regulation of patched by sonic hedgehog in the developing neural tube. Proc Nat Acad Sci USA 93: 9346-9348.

MARIGO, V., DAVEY, R.A., ZUO, Y., CUNNINGHAM, J.M. AND TABIN, C.J. (1996). Biochemical evidence that patched is the Hedgehog receptor. Nature 384: 176-9.

MARTÍ, E., BUMCROT, D.A., TAKADA, R., AND MCMAHON, A.P. (1995). Requirement of $19 \mathrm{~K}$ form of Sonic hedgehog for induction of distinct ventral cell types in CNS explants. Nature 375: 322-325.

MATHIEU, J., BARTH, A., ROSA, F.M., WILSON, S.W. AND PEYRIÉRAS, N. (2002). Distinct and cooperative roles for $\mathrm{Nodal}$ and Hedgehog signals during hypothalamic development. Development. 129: 3055-65.

MATISE, M.P., EPSTEIN, D.J., PARK, H.L., PLATT, K.A., AND JOYNER, A.L. (1998). Gli2 is required for induction of floor plate and adjacent cells, but not most ventral neurons in the mouse central nervous system. Development 125: 2759-2770.

MEYER, N.P., ROELINK, H. (2003). The amino-terminal region of Gli3 antagonizes the Shh response and acts in dorsoventral fate specification in the developing spinal cord. Dev. Biol. 257: 343-355

MUHR, J., ANDERSSON, E., PERSSON, M., JESSELL, T.M., AND ERICSON, J. (2001). Groucho-mediated transcriptional repression establishes progenitor cell pattern and neuronal fate in the ventral neural tube. Cell 104: 861-873.

MUTHU, V., EACHUS, H., ELLIS, P., BROWN, S. AND PLACZEK, M. (2016). Rx3 and Shh direct anisotropic growth and specification in the zebrafish tuberal/anterior hypothalamus. Development. 143: 2651-2663.

NISHI, Y., ZHANG, X., JEONG, J., PETERSON, K.A., VEDENKO, A., BULYK, M.L., HIDE, W.A., MCMAHON, A.P. (2015). A direct fate exclusion mechanism by Sonic hedgehog-regulated transcriptional repressors. Development 142: 3286-3293

NOVITCH, B.G., CHEN, A.I., JESSELL, T.M. (2001). Coordinate regulation of motor neuron subtype identity and pan-neuronal properties by the bHLH repressor Olig2. Neuron 31: 773-789

OHYAMA, K., ELLIS, P., KIMURA, S., AND PLACZEK, M. (2005). Directed differentiation of neural cells to hypothalamic dopaminergic neurons. Development 132: 5185-5197.

OHYAMA, K., DAS, R. AND PLACZEK, M. (2008) Temporal progression of hypothalamic patterning by a dual action of BMP. Development 135: 3325-3331.

OOSTERVEEN, T., KURDIJA, S., ALEKSEENKO, Z., UHOMEODOMAINE, C.W., BERGSLAND, M., SANDBERG, M., ANDERSSON, E., DIAS, J.M., MUHR, J., AND ERICSON, J. (2012). Mechanistic Differences in the Transcriptional Interpretation of Local and Long-Range Shh Morphogen Signaling. Dev. Cell 23: 1006-1019.

OOSTERVEEN, T., KURDIJA, S., ENSTERÖ, M., UHOMEODOMAINE, C.W., BERGSLAND, M., SANDBERG, M., SANDBERG, R., MUHR, J., AND ERICSON, J.
(2013). SoxB1-driven transcriptional network underlies neural-specific interpretation of morphogen signals. Proc. Natl. Acad. Sci. USA 110: 7330-7335.

ORQUERA, D.P., NASIF, S., LOW, M.J., RUBINSTEIN, M. AND DE SOUZA, F.S. (2016). Essential function of the transcription factor Rax in the early patterning of the mammalian hypothalamus. Dev Biol. 416:212-224.

PATTEN, I. AND PLACZEK, M. (2002). Opponent activities of Shh and BMP signaling during floor plate induction in vivo. Curr Biol. 12: 47-52.

PATTEN, I., KULESA, P., SHEN, M.M., FRASER, S., AND PLACZEK, M. (2003). Distinct modes of floor plate induction in the chick embryo. Development 130: 4809-4821.

PEARSON, C.A., AND PLACZEK, M. (2013). Development of the medial hypothalamus: forming a functional hypothalamic-neurohypophyseal interface. Cur. Top. Dev. Biol. 106: 49-88.

PEARSON, C.A., OHYAMA, K., MANNING, L., AGHAMOHAMMADZADEH, S., SANG, H., AND PLACZEK, M. (2011). FGF-dependent midline-derived progenitor cells in hypothalamic infundibular development. Development 138: 2613-2624.

PEPINSKY RB, ZENG C, WEN D, RAYHORN P, BAKER DP, WILLIAMS KP, BIXLER SA, AMBROSE CM, GARBER EA, MIATKOWSKI K, TAYLOR FR, WANG EA, GALDES A. (1998). Identification of a palmitic acid-modified form of human Sonic hedgehog. J Biol Chem. 273: 14037-14045

PERA, E.M. AND KESSEL, M. (1997) Patterning of the chick forebrain anlage by the prechordal plate. Development. 124: 4153-4162.

PERSSON, M., STAMATAKI, D., WELSCHER, TE, P., ANDERSSON, E., BÖSE, J., RÜTHER, U., ERICSON, J., AND BRISCOE, J. (2002). Dorsal-ventral patterning of the spinal cord requires Gli3 transcriptional repressor activity. Genes Dev. 16: 2865-2878.

PETERSON, K.A., NISHI, Y., MA, W., VEDENKO, A., SHOKRI, L., ZHANG, X., MCFARLANE, M., BAIZABAL, J.M., JUNKER, J.P., VAN OUDENAARDEN, A., MIKKELSEN T, BERNSTEIN BE, BAILEY TL, BULYK ML, WONG WH, MCMAHON AP. (2012). Neural-specific Sox2 input and differential Gli-binding affinity provide context and positional information in Shh-directed neural patterning. Genes Dev. 26: 2802-2816.

PLACZEK, M., AND BRISCOE, J. (2005). The floor plate: multiple cells, multiple signals. Nat. Rev. Neurosci. 6: 230-240.

PORTER JA, EKKER SC, PARK WJ, VON KESSLER DP, YOUNG KE, CHEN CH, MA Y, WOODS AS, COTTER RJ, KOONIN EV, BEACHY PA. (1996) Hedgehog patterning activity: role of a lipophilic modification mediated by the carboxy-terminal autoprocessing domain. Cell 86: 21-34

RIBES, V., BALASKAS, N., SASAI, N., CRUZ, C., DESSAUD, E., CAYUSO, J., TOZER, S., YANG, L.L., NOVITCH, B., MARTÍ, E., BRISCOE, J. (2010). Distinct Sonic Hedgehog signaling dynamics specify floor plate and ventral neuronal progenitors in the vertebrate neural tube. Genes Dev. 24: 1186-1200.

RIDDLE, R.D., JOHNSON, R.L., LAUFER, E., ANDTABIN, C. (1993). Sonic hedgehog mediates the polarizing activity of the ZPA. Cell 75: 1401-1416.

ROELINK, H., AUGSBURGER, A., HEEMSKERK, J., KORZH, V., NORLIN, S., RUIZ I ALTABA, A., TANABE, Y., PLACZEK, M., EDLUND, T., AND JESSELL, T.M. (1994). Floor plate and motor neuron induction by vhh-1, a vertebrate homolog of hedgehog expressed by the notochord. Cell 76: 761-775.

ROELINK, H., PORTER, J.A., CHIANG, C., TANABE, Y., CHANG, D.T., BEACHY, P.A., AND JESSELL, T.M. (1995). Floor plate and motor neuron induction by different concentrations of the amino-terminal cleavage product of sonic hedgehog autoproteolysis. Cell 81: 445-455.

ROESSLER, E., BELLONI, E., GAUDENZ, K., JAY, P., BERTA, P., SCHERER, S.W., TSUI, L.C., AND MUENKE, M. (1996). Mutations in the human Sonic Hedgehog gene cause holoprosencephaly. Nat Genet 14: 357-360.

ROESSLER, E., AND MUENKE, M. (2010). The molecular genetics of holoprosencephaly. Am J Med Genet C Semin Med Genet 154: 52-61.

ROHATGI, R., MILENKOVIC, L., AND SCOTT, M.P. (2007). Patched1 regulates hedgehog signaling at the primary cilium. Science 317: 372-376.

RUBIN, J.B., CHOI, Y., AND SEGAL, R.A. (2002). Cerebellar proteoglycans regulate sonic hedgehog responses during development. Development 129: 2223-2232.

SASAI, N., KUTEJOVA, E., BRISCOE, J. (2014). Integration of signals along orthogonal axes of the vertebrate neural tube controls progenitor competence and increases cell diversity. PLoS Biol. 12: e1001907

SCHOLPP, S., AND LUMSDEN, A. (2010). Building a bridal chamber: development of the thalamus. Trends Neurosci. 33: 373-380. 
SHIMAMURA, K., HARTIGAN, D.J., MARTINEZ, S., PUELLES, L, AND RUBENSTEIN, J.L. (1995). Longitudinal organization of the anterior neural plate and neural tube. Development. 121: 3923-3933.

SHIMAMURA, K., AND RUBENSTEIN, J.L. (1997). Inductive interactions direct early regionalization of the mouse forebrain. Development 124: 2709-2718.

SHIMOGORI, T., LEE, D.A., MIRANDA-ANGULO, A., YANG, Y., WANG, H., JIANG, L., YOSHIDA, A.C., KATAOKA, A., MASHIKO, H., AVETISYAN, M., QI L, QIAN J, BLACKSHAW S. (2010). A genomic atlas of mouse hypothalamic development. Nat. Neurosci. 13: 767-775.

SONG, J.Y., HOLTZ, A.M., PINSKEY, J.M. AND ALLEN, B.L. (2015) Distinct structura requirements for $\mathrm{CDON}$ and $\mathrm{BOC}$ in the promotion of Hedgehog signaling. Dev Biol. 402: 239-252.

STASIULEWICZ, M., GRAY, S.D., MASTROMINA, I., SILVA, J.C., BJÖRKLUND, M., SEYMOUR, P.A., BOOTH, D., THOMPSON, C., GREEN, R.J., HALL, E.A., SERUP, P. AND DALE, J.K. (2015). A conserved role for Notch signaling in priming the cellular response to Shh through ciliary localisation of the key Shh transducer Smo. Development 142: 2291-2303.

STAMATAKI, D., ULLOA, F., TSONI, S.V., MYNETT, A., AND BRISCOE, J. (2005). A gradient of Gli activity mediates graded Sonic Hedgehog signaling in the neural tube. Genes Dev. 19: 626-641.

SZABÓ, N.-E., ZHAO, T., ZHOU, X., AND ALVAREZ-BOLADO, G. (2009). The role of Sonic hedgehog of neural origin in thalamic differentiation in the mouse. J. Neurosci. 29: 2453-2466.

TENZEN, T., ALLEN, B.L., COLE, F., KANG, J.S., KRAUSS, R.S., AND MCMAHON, A.P. (2006). The cell surface membrane proteins $C$ do and Boc are components and targets of the Hedgehog signaling pathway and feedback network in mice. Dev. Cell 10: 647-656.

TROWE, M.-O., ZHAO, L., WEISS, A.-C., CHRISTOFFELS, V., EPSTEIN, D.J., AND KISPERT, A. (2013). Inhibition of Sox2-dependent activation of Shh in the ventral diencephalon by $\mathrm{Tbx} 3$ is required for formation of the neurohypophysis. Development 140: 2299-2309.

TUSON, M., HE, M., ANDERSON, K. V. (2011). Protein kinase A acts at the basa body of the primary cilium to prevent Gli2 activation and ventralization of the mouse neural tube. Development 138: 4921-4930

VAN STRAATEN, H.W., HEKKING, J.W., BEURSGENS, J.P., TERWINDT-ROUWENHORST, E., AND DRUKKER, J. (1989). Effect of the notochord on proliferation and differentiation in the neural tube of the chick embryo. Development 107: 793-803.

VAN STRAATEN, H.W., HEKKING, J.W., WIERTZ-HOESSELS, E.J., THORS, F., DRUKKER, J. (1988). Effect of the notochord on the differentiation of a floor plate area in the neural tube of the chick embryo. Anat. Embryol. (Berl). 177: 317-324.
VIEIRA, C., GARDA, A.-L., SHIMAMURA, K., AND MARTÍNEZ, S. (2005). Thalamic development induced by Shh in the chick embryo. Dev. Biol. 284: 351-363.

VOKES, S.A., JI, H., MCCUINE, S., TENZEN, T., GILES, S., ZHONG, S., LONGABAUGH, W.J.R., DAVIDSON, E.H., WONG, W.H., AND MCMAHON, A.P. (2007) Genomic characterization of Gli-activator targets in sonic hedgehog-mediated neural patterning. Development 134: 1977-1989.

VOKES, S.A., JI, H., WONG, W.H., AND MCMAHON, A.P. (2008). A genome-scale analysis of the cis-regulatory circuitry underlying sonic hedgehog-mediated patterning of the mammalian limb. Genes Dev. 22: 2651-2663.

VUE, T.Y., AAKER, J., TANIGUCHI, A., KAZEMZADEH, C., SKIDMORE, J.M., MARTIN, D.M., MARTIN, J.F., TREIER, M., AND NAKAGAWA, Y. (2007). Characterization of progenitor domains in the developing mouse thalamus. J. Comp. Neurol. 505: 73-91.

WANG, M.Z., JIN, P., BUMCROT, D.A., MARIGO, V., MCMAHON, A.P., WANG, E.A. WOOLF, T., PANG, K. (1995). Induction of dopaminergic neuron phenotype in the midbrain by Sonic hedgehog protein. Nat Med. 1: 1184-1188.

WATANABE, Y. AND NAKAMURA, H. (2000). Control of chick tectum territory along forsoventral axis by Sonic hedgehog. Development 127: 1131-1140.

WICHTERLE, H., LIEBERAM, I., PORTER, J.A., AND JESSELL, T.M. (2002). Directed differentiation of embryonic stem cells into motor neurons. Cell 110: 385-397.

WIJGERDE, M., MCMAHON, J.A., RULE, M., AND MCMAHON, A.P. (2002). A direct requirement for Hedgehog signaling for normal specification of all ventral progenitor domains in the presumptive mammalian spinal cord. Genes Dev. 16: 2849-2864

YAMADA, T., PLACZEK, M., TANAKA, H., DODD, J., AND JESSELL, T.M. (1991) Control of cell pattern in the developing nervous system: polarizing activity of the floor plate and notochord. Cell 64: 635-647.

YAMADA, T., PFAFF, S.L., EDLUND, T. AND JESSELL, T.M. (1993) Control of cell pattern in the neural tube: motor neuron induction by diffusible factors from notochord and floor plate. Cell 73: 673-686.

YIN, Y., BANGS, F., PATON, I.R., PRESCOTT, A., JAMES, J., DAVEY, M.G., WHITLEY, P., GENIKHOVICH, G., TECHNAU, U., BURT, D.W., TICKLE, C. (2009) The Talpid3 gene (KIAA0586) encodes a centrosomal protein that is essential for primary cilia formation. Development 136: 655-664.

ZAGORSKI, M., TABATA, Y., BRANDENBERG, N., LUTOLF, M.P., TKAČIK, G. BOLLENBACH, T., BRISCOE, J., KICHEVA, A. (2017). Decoding of position in the developing neural tube from antiparallel morphogen gradients. Science 356: $1379-1383$

ZHAO, L., ZEVALLOS, S.E., RIZZOTI, K., JEONG, Y., LOVELL-BADGE, R. AND EPSTEIN, D.J. (2012). Disruption of SoxB1-dependent Sonic hedgehog expression in the hypothalamus causes septo-optic dysplasia. Dev Cell. 22: 585-596. 


\section{Further Related Reading, published previously in the Int. J. Dev. Biol.}

Temporal and spatial expression patterns of Hedgehog receptors in the developing inner and middle ear Jeong-Oh Shin, Harinarayana Ankamreddy, Naga Mahesh Jakka, Seokwon Lee, Un-Kyung Kim and Jinwoong Bok Int. J. Dev. Biol. (2017) 61: 557-563

https://doi.org/10.1387/ijdb.170155jb

Scale development in fish: a review, with description of sonic hedgehog (shh) expression in the zebrafish (Danio rerio) Jean-Yves Sire and Marie-Andrée Akimenko

Int. J. Dev. Biol. (2004) 48: 233-247

http://www.intjdevbiol.com/web/paper/15272389

Unusual pattern of Sonic hedgehog expression in the polydactylous mouse mutant Hemimelic extra-toes Isabelle Blanc, Antoine Bach and Benoît Robert

Int. J. Dev. Biol. (2002) 46: 969-974

http://www.intjdevbiol.com/web/paper/12455636

Exogenous retinoic acid induces a stage-specific, transient and progressive extension of Sonic hedgehog expression across the pectoral fin bud of zebrafish

Lisa Hoffman, Jennifer Miles, Fabien Avaron, Lynda Laforest and Marie-Andrée Akimenko

Int. J. Dev. Biol. (2002) 46: 949-956

http://www.intjdevbiol.com/web/paper/12455633

Patterning of the vertebrate ventral spinal cord

Alisa Poh, Asanka Karunaratne, Gabriel Kolle, Ning Huang, Emma Smith, Joanna Starkey, Daying Wen, Ian Wilson, Toshiya Yamada and Murray Hargrave

Int. J. Dev. Biol. (2002) 46: 597-608

http://www.intjdevbiol.com/web/paper/12141448

Expression of axial and sonic hedgehog in wildtype and midline defective zebrafish embryos

U Strähle, P Blader and P W Ingham

Int. J. Dev. Biol. (1996) 40: 929-940

http://www.intjdevbiol.com/web/paper/8946241

Sonic hedgehog: a common signal for ventral patterning along the rostrocaudal axis of the neural tube

$\mathrm{J}$ Ericson, J Muhr, T M Jessell and T Edlund

Int. J. Dev. Biol. (1995) 39: 809-816

http://www.intjdevbiol.com/web/paper/8645565

5 yr ISI Impact Factor $(2016)=2.421$
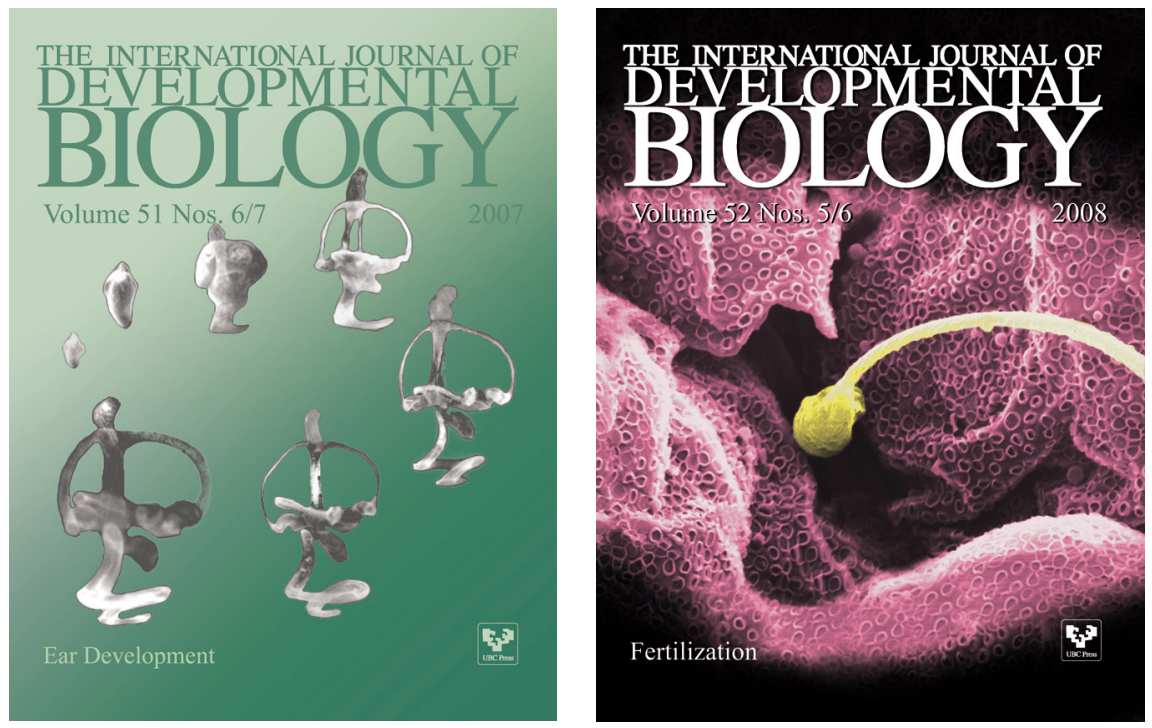

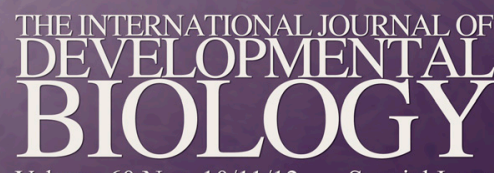

Volume 60 Nos. $10 / 11 / 12$

Special Issue
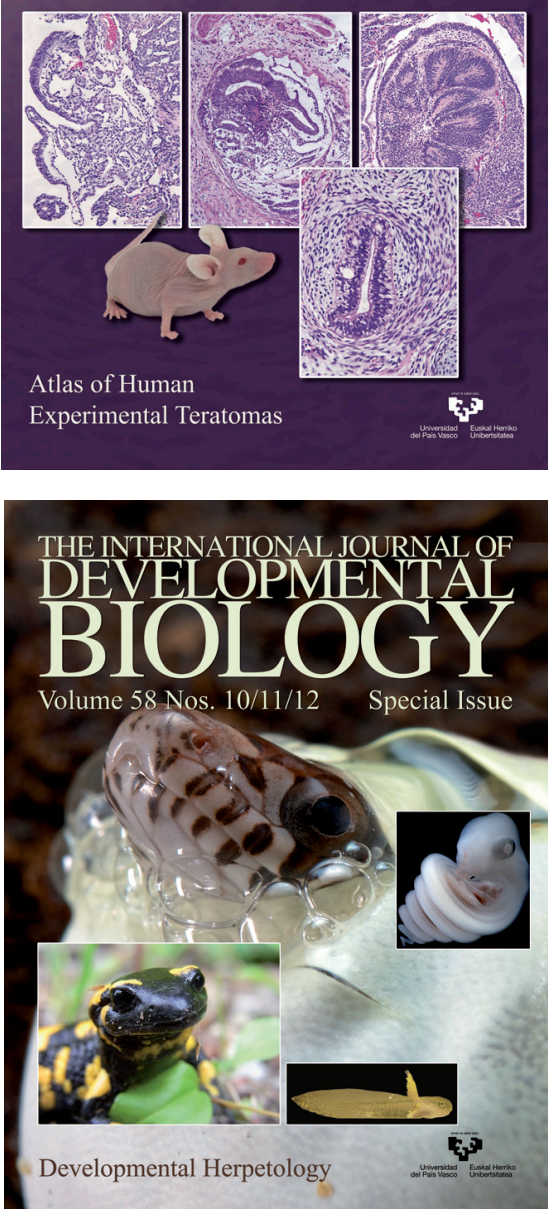